
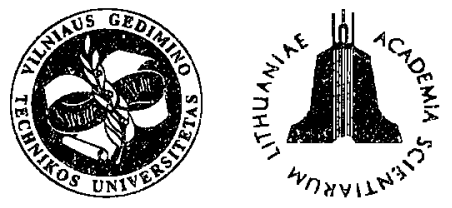

ISSN 1548-4142 TRANSPORT

http:/www.vtu.lt/english/editions

\title{
INTERACTION OF THE KLAIPEDA SEA PORT AND RAILWAY TRANSPORT
}

\author{
Raimondas Burkovskis ${ }^{1}$, Ramūnas Palšaitis ${ }^{2}$ \\ Iilnius Gediminas Technical University, Plytinès 27, LÄ-2040 Vilnius, Lithuania
}

Received 200202 07; accepted 20020304

\begin{abstract}
This article offers the panoramic view to interoperability of sea and railway transport in Lithuania. Serious attention is being given to the cargo flows forecasts, analysis of geographic, political, legal, economical, technical and other factors influencing the intensity of transit cargo flows and using the existing infrastructure capacities. Improvement and further development of technological and rechnical base of railways for the development of container transportation is identified. Optimization of tariffs (railway + port) will increase the competitiveness of corridor $Y \mathcal{B}$ for transit cargo and traffic flows.
\end{abstract}

Keywords: competitiveness, interoperability, port, railway, flows, cargo.

\section{Introduction}

Since the first years of Lithuania's independence the image of the country is being established as that of a transit country which by its international transport corridors connects Western and Eastern, as well as Southern and Northern countries $[1,2]$. This was predetermined by the importance of transit transportation for the economic life. Income from transit services creates the major part of the country's GDP and establishes thousands of working places.

The above circumstances also determine a new approach to the transit system as to a uniform multimodal process [3-7]. In this case services provided to customers are to comprise a full complex of logistics, including transportation of goods, storing, customs clearence procedures, formal arrangements of documents, services etc.

A very important role in the transit chain is played by the sea and railway transport. The Interaction of the sea and railway transport can be characterised by common interests in order to attract transit cargoes and to use (maximally) the existing infrastructure capacities and, due to new investments and marketing, to assure the functioning of common multimodal system in future by attracting new cargoes.

\section{Cargo Flows}

Via the Baltic ports the flows of cargoes from Russia, Belarus, Ukraine, Kazakhstan and many other countries are performed.

'E-mail: burkovskis@delfi.lt

${ }^{2}$ E-mail: ramunas.palsaitis@ti.vtu.1t
It is envisaged that the activities of the Baltic States ports will increase considerably because of cargo flows. That is why the ports of Lithuania, Estonia and Latvia are constantly improving their performance orienting their activities to cargo transit. The following activities were performed in the ports: deepening of water area, increasing of warehouse space, construction of new container terminals, huge complexes for oil and oil repumping and storing. Efforts are made in order to retain existing tarififs of cargo handling and transportation. Cenires of logistics are established and foreign investments are atiracted in order to improve the quality of activities.

Currently various Russian authorities support the policy of directing Russian cargoes to the ports of Russia.

The anticipated amount of cargo flows is forecast differently: some scientists envisage the amount of cargoes in 2010 up to 400 million tones per year, from which Russia would handle only 150 million tons. However the Russian scientists themselves are more pessimistic. In 2010 their forecast increase of cargo flows is $20-30 \%$. It is anticipated that in 2020 services of transport in ports will exceed the demand by $2-3$ times.

The above perspective determines the development of various services in the ports and transition from narrow specialization to wider universality. This tendency is felt watching the efforts of the ports to attract new cargoes (containers in the first place). Evaluating the already existing terminals it becomes obvious that the comperition among ports will increase in future.

The Lithuanian Government understands the importance of transit for the economy of the country and pays more attention to multimodal transportation; it also considers the process of cargo transportation as an inseparable transport chain. Railway transport comprises 
a part of this chain and is the main supplier of cargoes to the Klaipeda port. The railway transport in Lithuania delivering cargoes to the port has to compete not only with road transport, but also with railways. Especially sharp competition with Estonian and Latvian railways is being observed this year.

Railways may become one of the major hindrances for the rapid development of the port which determines the decrease of cargo flows due to its obsolete rollingstock, awkward monopolic enterprise with ineffective management, shortage of funds, the state's interference into the activities of the enterprise as well as many other factors.

In order to avoid all the above it is necessary to proceed with railway restructuring improving the management of enterprises, seeking higher efficiency and flexibility of activities, solving problems of infiastructure financing, subsidies for passenger transportation, separating the functions not characteristic to railways, decreasing the interference of the state into economic activities and assuring liberalisation of tariffs and transportation market.

Evaluating the above the conclusion might be made that many factors depending on various conditions influence the transit of cargoes. The main of these are as follows:

- Geographic and natural factors;

- Political, legal and economic factors;

- Security, technological, qualitative and quantitative factors;

- Pricing and tariff policy factors.

Some of these factors prevail and are more evident in one country and some - in other countries. Thus, increasing competitiveness it is necessary in the first place to develop and present national advantages trying at the same time to reduce the differences among other less advantageous factors.

\section{Geographic and Natural Factors}

Lithuania in terms of geographic situation is less attractive to the Russian transport and cargoes than Latvia and Estonia. The major disadvantage is a longer distance from the main Russian economic centres to Klaipeda, as well as crossing of the territory of Belarus. On the other hand the Klaipeda port is an ice-free port in the very North which can accept vessels throughout the year.

The depth of the port water area and the entrance to the port partly determine the distribution of cargo flows in the ports.

Another geographic advantage of Lithuania is that the closest transit road to Kaliningrad runs via Lithuania and this stipulates common interests in the negotiations with Russia.

\section{Political, Legal and Economic Factors}

These factors are expressed by international agree- ments, legal regulations, resirictions and other factors stipulating or restricting volumes of cargo transit as well as interaction between railway and port.

Interaction between railway and port first of all has to be expressed by the establishment of common transit policy. It is necessary to understand that certain hindrances in one part of the system will have a negative impact on the entire system. Thus, close co-operation among the port companies and railway enterprises is necessary involving also responsible representatives of the state institutions.

The Lithuanian Government establishes the state transit policy with the help of the Transport Transit Committec. The implemencing authority is the Ministry of Transport and Communications as well as the institutions under its regulation sphere [8]. However, raking into account economic opportunities it is difficult to expect financial support from the state for the implementation of vital projects.

So far the Lithuanian Government has no specific strategy for cargo transit via the territory of Lithuania. The absence of this strategy caused disputes inside the country and they were mostly related to privatisation of the most important sea shipping companies - "Lithuanian Sea shipping" and "Klaipeda Transport Fleet" as well as to absence of a clear vision related to the perspective of the above companies. Currently the fears seem to be quite mocivated, i.e. that, after the privatisation of the "Lithuanian Sea shipping", Lithuania can loose its fleet as well as the control of one of the transit chains, i.e. transportation by sea. This would not have happened if perspectives for shipping activities as well as its place in the transit system and limits of the state's interference into the activities of the company were set out in due time. A probability exists that the same will happen after the privatisation of the Lithuanian Railways.

Comparing Lithuania with Estonia and Latvia, a certain lacking behind in the practical management of transit policy is observed. Up to 1999 the image of Lithuania as a transit country was insufficiently popularised. The co-operation among private and state enterprises and state institutions was insufficient, especially in terms of legal acts. That is why new legal acts limit transit to new restrictions instead of promoting this type of activity.

Firstly it concerns the law of Klaipeda free port. The law incurred many discussions among various Lithuanian authorities and even made the Lithuanian President suspicious that those who created the laws have created preconditions for the officials to make profit and legalise unconscientious competition. Another step is a draft of a security organisation in the Klaipeda state seaport prepared by the Ministry of Transport and Communications.

This draft contradicts many legal acts ascribed to the Klaipeda sea port since the Ministry of Transport and Communications and the Klaipeda State seapori Authorities are not to be responsible for the security of the port 
territory. These functions are not characteristic of the above state institutions. The draft was prepared not taking into account the opinion and financial capacities of the port stevedoring companies. The amount of 54 million of litas anticipated for the implementation of the security draft project could be allocated for the development of infrastructure of the port but not for the implementation of the entrance or gate security measures. The port authority which is responsible for the development of infrastructure might not have enough funds for investment to quays and deepening of the water area. This might also have impact on cargo flows.

One of the major hindrances for the improvement of the interaction between the port and railway and popularising the image of transit of the country is the problem of customs procedures. In this respect Lithuania is lacking behind other Baltic States.

Current customs clearance procedures for transit cargoes are regulated by the Customs Code of the Republic of Lishuania, Decree No. 1610 adopted by the Lithuanian Government in 1995, Decree No.78 adopted by the Lithuanian Government in 1999 as well as by other legal documents. Many of these legal acts are complicated, contradicting to each other, incur additional hindrances and reduce attractiveness of Lithuania as a transit country.

Customs clearance procedures at the railway border stations and in the Klaipeda port take a lot of time (e.g. filling in transit declarations) and increase general cargo transportation costs. The formal registration of trains requiring to fill in transit declarations in the Klaipeda port takes up to 20 hours for each train. Filling in transit declarations for each wagon or each package in the wagon increases the price up to 2-4 litas per tone. At the same time the neighbouring countries use SMGS invoices and there is no need to fill in transit declarations. Consequently time expenditure and transportation costs are reduced.

There are many problems also at the customs posts. In the Klaipeda port which covers 1038 hectares there are more than 20 various companies. From all these companies cargoes or goods necessary for their economic activities are imported and exported through the port gates by hinterland. The gates serve for road and railway transport, that is why there are many entrances. The Lithuanian Government and Customs Department seek to decrease the number of gates. However then cargoes will have to move through the territories of several companies to one gate. This will make long queues and this does not correspond to the objective to simplify all the procedures to help the cargo cross certain gates or borders.

Another problem is the organization of activities at customs posts in the Klaipeda port, since due to organizational shortcomings customs procedures cannot be finished in one post. From 1 March 1999 rules for transportation, storage and checking of goods in the port complex zones supervised by the customs existing in the territory of the control posts of the Klaipeda sea port were started to be applied. Due to the latter requirements many problems occur for wagons with technical and commercial spoilage from western countries. Without eliminating the spoilage it is impossible to take the goods out or bring back from/to the customs territory within 24 hours since this is required by rules. On the other hand by taking such a cargo out a risk is to have administrative responsibility as for the infringement of the rules on the operations of railway transport measures. Many other problems in organization of customs activities are met in other stations and roads of the Klaipeda railway hub of the port.

Separate legal acts transfer the responsibility of cargo owners or their authorised representatives to the users of the port or to the railway enterprise for timely clearance of customs procedures, although the latter, unless they are authorised representatives of cargo owners, cannot perform this activity at all.

Thus, the customs procedures in terms of transit cargo are not perfect; consequently, the image and attractiveness of the Klaipeda port, Lithuanian Railways and Lithuania as a transit country decreases.

\section{Security, Technological, Qualitative and Quantitative Factors}

Security, technological, qualitative and quantitative factors are characterised by the level and status of infrastructure and used technologies, determining the qualitative and quantitative transport indicators and perspectives.

As private capital has prevailed in the Klaipeda port, the investment to new technologies increased, the approach to work organization has changed. However a very important problem still is the status of the port infrastructure (quays, port entrance). This hinders the rapid development of the port.

The current port piers do not protect the piers of the „Klaipeda Oil" from storms and a narrow entrance is dangerous for the security of vessels. In 03 August 2000 loan and state guarantee agreements with the World Bank were signed on the financing of the reconstruction project of the port entrance. The implementation of this project will allow not only to increase competitiveness of the port in the Eastern part of the Baltic, but will also improve the conditions of the sea environment. This is one of the most important projects to improve the security of the port.

The Klaipeda port is famous for its universality and capacity to handle various cargoes. As it was mentioned a very important factor which determined the type and size of vessels entering the port is the depth of the water area and the length of piers. For example, after having deepened the port channel up to 14 metres, the port could be entered by $80000 \mathrm{dwt}$ tankers instead of $30000 \mathrm{dwt}$ tankers. However so far the millions spent on deepening of the port channel did not give substantial results, since the dwarf of vessels entering the port has not changed.

In order to assure maximally the activities of the port 
coherent development of all inirastructure elements as well as of the technical status are necessary. The railway hub of the Klaipeda port is one of the important elements. It includes Klaipeda, Draugyste, Rimkai railway stations as well as Pauostis, Angline roads and access roads. Both highways and station railways are in a bad condition, in many places the speed of trains is restricted, iraffic security is insufficient. Railway in the Klaipeda port is one of the bottlenecks due to its bad condition, low speed and capacities and all them hinder cargo handling in the port.

The Railway hub modernisation programme approved in 1998 is practically not implemented due to the shortage of funds and lack of state support. The same can be said about Pauostis road which after modernisation of "Klaipeda Oil" will not assure normal activities of the enterprise.

Evaluating the perspective co-operation directions of the Klaipeda seaport and railway it is necessary to prepare technological and technical base of railway for the development of container transportation. The latter reflects common development of intermodal transportation in the world and has one of the biggest potentials in the transit market of the Baitic States. It is envisaged that in the nearest future flows of container cargoes via the Baltic Sea will increase by three times.

Currently the Lithuanian railways have not yet found their place in the container transport, however it is necessary to use the existing advantages. First of all this concerns lower prices, operability, possibility to transport big amounts, less restrictions to cargo mass and size. The road transport is more attractive due to its mobility, flexibility and speed.

Shuttle trains can be opposed to road transport.

Finally it can be stated that a very important factor is the development of infrastructure and services of railways in accordance with the European Union standards, technological, technical and organisational directions.

Firstly, it is necessary to eliminate bottlenecks in railway infrastructure, i.e. to eliminate capital repairs of the track, modernise signalling and telecommunication equipment, reconsiruct and develop the port railway hub. Having implemented the port reconstruction and modernisation activities (improvement of the port entrance channel, deepening of the water area, reconstruction of piers etc.) an effective and attractive infrastructure could be established and comprehensive railway and port interaction assured.

\section{Pricing and Tariff Policy Factors}

Investigating general transport costs via Lithuania it is necessary to consider the main groups of expenditure, i.e. the port duties, prices of cargo forwarding and shipping, costs of customs procedures, costs of cargo handling in the port, tariffs for services provided by railways and other additional duties [9-12].
Implementing the Decree No. 424 of the Lithuanian Government (14 April 2000) maximum tariffs of cargo transportation by railways are confirmed by the Ministry of Transport and Communications in co-ordination with the Transport Transit Committee and Competition Council. Specific tariffs for cargo transportation by railways are defined by the Board of Lithuanian railways according to the rules of tariff definition for cargo transportation by railway transport.

SCSP „Lithuanian Railways", as a member of transport market and as an economic unit, should get an opportunity to define not only factual but also the base tariffs. In the opposite case flexibility will be missing in solving tariff problems and this will take much time; a possibility is being created for the lobistic activities of persons having influence on these decisions.

Many of tariffs applied by the Lithuanian Railways are lower that in the neighbouring Baltic States. It especially concerns wood, fertilisers, etc. Black metal, diesel fuel tariffs are similar to those of the Latvian railways, however they are lower than the Estonian ones. Generally tariffs of the Lithuanian Railways are competitive in terms of other Baltic states. However, very often Lithuania looses to Latvia in terms of transport distance, which, in comparison with other major Russian economic centres is much longer.

When the Russian Federation started implementing its transport policy directed towards the reorientation of Russian cargoes to the Russian ports and after the elimination of tariff discounts valid in transporting cargoes via Lithuania, the competitiveness of the Klaipeda port decreased. Currently it is necessary to negotiate on discounts to different cargoes and routes and to cooperate closely with entrepreneurs of Kaliningrad trying to win tariff discounts. However it is necessary to harmonise tariffs in Klaipeda and Kaliningrad directions eliminating the existing discrimination.

In order to increase the competitiveness of the Klaipeda port it is necessary to evaluate cargo tariffs and railway tariffs in the port and look for the ways of to reducing them. The reduction of railway tariffs alone will not be of great use, since, comparing with the port handling tariffs, the costs for transportation of some goods via Lithuania by railway are lower by two times.

For example, investigating metal transportation and handling tariffs, the situation is as follows: base tariff for the transportation of metal via Lithuanian territory is 4.41 USD per tone, and base tariff for handling in the port reaches 8.5 USD. Of course, with certain discounts applied (these comprise up to $25 \%$ ) this price decreases, however in any case it remains higher than railway tariffs.

Generally base tariffs of handling in the Klaipeda port are similar to those in the Baltic states, so discounts, quality of cargo handling, possible big amount at a time (usage of vessels) etc. influence the choosing of the port considerably. 
Optimisation of tariffs (railway+pori) has direct influence on the increase of the competitiveness of specific transport routes, thus it is very important to look for the possible ways and make an agreement in the entire corridor. This would allow to optimise transportation prices and to retain them in the entire route.

In order to liberalise tariff and transportation market it is necessary to involve private carriers assuring equivalent competition and equal conditions for activities. The role of the State in the market must be strictly regulated and restricted to solving strategic political problems and non-interference of the state into the economic activities.

\section{Correlusions}

1. A very important role in the transit chain is played by sea and railway transport. Interactivity of sea and railway transport can be characterised by common interests in order to attract transit cargoes and to use maximally the existing infrastructure capacities and, due io new investments and marketing, to assure functioning of common multimodal system in future by attracting new cargoes.

2. One of the major hindrances for the improvement of interactivity between the port and railway and in popularising the image of transit of the country is a problem of customs procedures. In this respect Lithuania is lacking behind other Baltic Stakes. Thus the customs procedures in terms of cargo transit are not perfect; consequently, the image and attraciveriess of the Klaipeda port, Lithuanian Railways and Lithuania as a transit country decreases.

3. In order to assure maximally the activities of the port coherent development of all infrastructure elements as well as of the technical status are necessary. The railway hub of the Klaipeda port is one of the important elements. Railway in the Klaipeda port is one of the bottlenecks due to its bad condition, low speed and capacities and all of them hinder cargo handling in the port.

4. Evaluating the perspective co-operation directions of the Klaipeda seaport and railway it is necessary to prepare technological and technical base of railway for the development of container transportation. Currently the Lithuanian railways have not yet found their place in the container transport, however it is necessary to use the existing advantages.
5. In order to increase the competitiveness of the Klaipeda port it is necessary to evaluate cargo tariffs and rail way' tariffs in the port and look for the ways of reducing them. Optimisation of tariffs (railway + port) has direct influence on the increase of the competitiveness of specific transport routes, thus it is very important to look for the possible ways and make an agreement in the entire corridor.

\section{References}

1. Šakalys A., Jaržemskis V., Zubkevičius A. New Way to Europe. Transport. Ports. Logistics. Riga: 000 Transporta informacijas centrs. No 16, 1999, p $40-42$.

2. Vidžiūnaite G., Pranevičius H., Palšaitis R. Results of Modeling East-West Multimodal Transport. KTU. 1997. p 257 - 263 (in Lithuanian).

3. Cantarella G. E., A General Fixed-Point Approach to Multimodal Multi-user Equilibrium Assignment with Elastic demand. Transportation Science, Vol 31, 1997, p $107-128$.

4. Fiquet $C$. Intermodal transpori can solve Europe's transport problems. European railway review. No 5/1, 1999. $25 \mathrm{p}$.

5. Newmanand A. M., Yano C. A. Scheduling Direct and Indirect Trains and Containers in an Intermodal Setting. Transport Science, Vol 34, 2000, p 220 - 270.

6. UIRR. Developing Intermodal Connections with Eastern Europe. Statement of the UIRR. Brussels: UIRR, 1996. $120 \mathrm{p}$.

7. Mačiulis A., Palšaitis R. Railway Restructuring and Development of Multimodal Transpon. Vilnius Technical University scientific joumal. Transport Engineering, No 1 (14), 1997, p 9 - 17 (in Lithuanian).

8. Paliulis N., Palšaitis R. Principles of govemmental regulation of transport activities in Lithuania. Vilnius Technical University scientific journal. Transport Engineering. No 3 . (14), 1999, p 153 - 157.

9. Cole M. CT: Is Price its Only Atraction? European Railway Review, No 3/1. London: RusselI Publishing Ltd., 1999, p $78-81$.

10. Dodgson J., Palšaitis R., Fus G., Villemi M., Waldren R. Urban public transport in the Baltic states. Transport Reviews, Vol 18, No 2, 1998, p 153 - 163. UK.

11. Public Infrastructure Charging Systems. Ministry of Transport of the Republic of Lithuania. Vilnius, 1998. $56 \mathrm{p}$ (in Lithuanian).

12. Palšaitis R., Burkovskis R. Analysis of cargo and passengers transportation tendencies in the Lithuania railway system. Vilnius Technical University scientific journal. Transport Engineering, No 2, 1999. 